\title{
Thinking on Wealth Management Education in Marketing Specialty Construction
}

\author{
Chongmei Wang*, Zening Qu \\ School of Management \\ Shandong Technology and Business University \\ Yantai 264005, China
}

\begin{abstract}
This research takes the curriculum system design and teaching content reform of marketing specialty and marketing course as the research content. Through the analysis, we can connect and cooperate with the teaching work of other courses, because students' wealth creation ability cannot be completely cultivated through one course. It needs the basic and progressive development. At the same time, it needs study how to consolidate and improve the ability learned by students in other courses before through classroom teaching, integrate the existing ability of students with the ability required by existing courses, and cultivate students' innovative compound wealth creation ability.
\end{abstract}

Keywords-marketing; wealth management; specialty construction

\section{INTRODUCTION}

\section{A. Research Background}

In August 2018, the Ministry of education especially issued the notice on the implementation of the spirit of the national undergraduate education work conference of colleges and universities in the new era (no. 8, 2018), proposing that "Colleges and universities should comprehensively comb the teaching content of each course, eliminate 'water course', create 'gold course', and effectively improve the teaching quality of courses." At present, the educational reform of ability cultivation mainly focuses on the reform of cultivating students' certain ability in research courses. We think of college students in colleges and universities, should have innovative compound wealth creation ability, and is not just a kind of ability.

\section{B. Research Significance}

(1) How to consolidate and improve students' ability learned in other courses through classroom teaching, integrate students' existing ability with the ability required by existing courses, and cultivate students' innovative and complex wealth creation ability.

(2) Students' wealth creation ability cannot be completely cultivated through one course. Through in-depth research and analysis, the marketing course and other courses to connect and match the teaching work.
(3) To build high-quality resource-sharing courses, the goal is to realize high-quality teaching resource sharing. Choose 2-3 courses for marketing majors, including offline "golden courses", online "golden courses", online and offline mixed "gold course", virtual simulation "gold course" and social practice "gold course".

\section{RELEVANT THEORIES}

\section{A. Finance and Business Education}

Financial quotient, originally referred to as "financial intelligence", refers to the ability of individuals or groups to recognize, create and manage wealth, that is financial IQ and financial wisdom, which includes three levels and four skills of concept, knowledge and behavior. Concept refers to the cognition and understanding process of money and wealth, including the concept of money, rational consumption, active entrepreneurship, conscious investment and scientific financial management; Knowledge is an essential accumulation of knowledge for investment and entrepreneurship, which is embodied in four kinds of knowledge, namely accounting knowledge, legal knowledge, investment knowledge and market knowledge; As the expression and carrier of concept, behavior is the interaction of concept and knowledge between individual and environment, which is embodied in the quality and ability of self-breakthrough, self-activation and self-control. The three aspects complement each other and support each other to form a dynamic development system. The four main skills include: first, the ability to read and understand numbers; second, the ability to generate money with money; third, the ability to market, supply and demand, and meet market demand fourth, the ability to reasonably use laws and regulations, relevant accounting, laws and tax regulations.

To promote quality education and make higher education meet the needs of social development: to vigorously promote quality education and cultivate compound talents to adapt to economic and social development is the ultimate goal of university education. Compound talents should not only have solid professional knowledge, but also master some necessary knowledge of economy, management, law and other aspects as well as the ability to obtain happiness, which are inseparable from the quality of the personal financial improvement. Correct concept of wealth and strong ability of wealth management are 
undoubtedly the necessary conditions for individuals and families to achieve happiness and success.

\section{B. Quality Education}

Quality education is an education with the fundamental purpose of comprehensively improving people's basic quality, respecting people's subjectivity and initiative spirit, based on people's character, focusing on the development of people's wisdom potential, and focusing on the formation of people's sound personality. To promote quality education and make higher education adapt to the needs of social development: to vigorously promote quality education and cultivate compound talents to adapt to economic and social development is the ultimate goal of university education. Compound talents should not only have solid professional knowledge, but also master some necessary knowledge of economy, management, law and other aspects as well as the ability to obtain happiness, which are inseparable from each other The improvement of people's financial and business quality. Correct concept of wealth and strong ability of wealth management are undoubtedly the necessary conditions for individuals and families to achieve happiness and success.

\section{Innovative Talents}

Innovation is the soul of a nation's progress and the inexhaustible power of a country's prosperity. Personnel training mode refers to providing students with knowledge structure, ability structure, quality structure and the ways and methods to realize these structures according to the objectives and quality standards of personnel training. The training mode of innovative compound talents is based on acquiring knowledge, combining theory with practice, developing innovative ability as the core, and improving comprehensive quality as the goal.

\section{Compound Talents}

The so-called compound talents are those who have more than two subjects of knowledge and can engage in interdisciplinary research. In other words, they are all kinds of applicable talents with strong subject knowledge, wide range of knowledge, strong adaptability, innovative spirit and creative ability, that is, those who master knowledge and skills of various subjects and are full of creativity. Compound talents need three basic qualities: knowledge, skill and attitude. Marx's theory of human's all-round development, quality education, multiple intelligences and the theory of human capital specialization are the theoretical basis of training compound talents. Compound talents are the needs of the times and the development of human beings.

\section{ANALYSIS AND SUMMARY OF THE STATUS QUO OF WEALTH MANAGEMENT EDUCATION AND TRAINING}

\section{A. Current Status of Wealth Management Training in China}

1) The simplification of wealth management content and form.

With the continuous increase of personal wealth in China, wealth management has also made certain progress. However, compared with some foreign developed capitalist markets, neither the content of wealth management nor the form of wealth management in China is very mature, which needs to be further improved and perfected. The form of wealth management in China is not limited to a single investment and access, but should also move toward diversification in order to seek better development.

2) The development speed of wealth management in China is relatively slow.

Compared with the developed capitalist countries in Europe and the United States, China's wealth management is still in a relatively primary stage, and its development is relatively slow. Chinese people's long-formed concept of financial management, to some extent, has brought some negative effects on China's difficulty in making substantive progress in wealth management. However, the development speed of those small-scale wealth management and China's economic development is still slow.

3) The development of wealth management education in China is limited.

The lack of a good social and market atmosphere is not just a problem in the education sector. The deeper root lies in the misconceptions of wealth in the whole society. To popularize wealth management education, we must first cultivate a wave of wealth management learning. Among them, financial education of young people and entrepreneurs is the inevitable requirement of development.

\section{B. Future Trends of Wealth Management-related Training}

1) Wealth management institutions are developing towards specialization.

China's wealth management institutions also need to become more and more professional, constantly improve and perfect. From a long-term perspective, with the continuous expansion of China's wealth management scale and the continuous promotion of national policies, there will be a group of excellent financial management institutions in the market, which is an inevitable development trend.

2) Wealth management continues to be internationalized

Internationalization is the general trend, wealth management training institutions must have the ability to internationalize. We will continue to innovate the mode, make use of big data, provide intelligent and personalized wealth management training services, and build an international platform for wealth management personnel training.

\section{ENLIGHTENMENT}

We can get some enlightenment from analyzing the behavi oral characteristics of wealth management of social groups and sorting, summing up and reporting questionnaires.

(1) After mastering certain knowledge and analyzing how to conduct wealth management, we can learn to weigh the advantages and disadvantages and choose the appropriate way to conduct wealth management from the perspective of personal economic status to maximize our own wealth. 
(2) The relevant courses and theories of construction reform, quality education and basic education needed by innovative and compound wealth management talents have provided relevant theoretical basis for the research and questionnaire design, and guided the completion of relevant practical activities.

(3) For the behavioral characteristics of wealth management and questionnaire design of social groups, the members of the research team should pay attention to whether the design of the questions is targeted, whether it follows the research topic, and whether it is simple, clear and easy to understand.

(4) Reliability analysis, validity analysis and model building enable us to learn relevant professional knowledge and skills. Moreover, the accuracy, consistency and stability of reliability analysis and validity analysis, as well as the intuitiveness of the model, increase the credibility of the questionnaire results and make the survey report more convincing. We can use these methods for reference in future related activities.

(5) Finally, according to the survey report, the cultivation of innovative and compound financial management talents in China is not very mature at the present stage, and colleges and universities are making continuous efforts to this end. This process requires us to continue to explore and try, we should combine the current stage of China\&apos; s educational development strength and students\&apos; ability to accept to find the training methods suitable for the actual situation.

\section{CONCLUSION}

Financial intelligence education can help college students to establish a correct concept of wealth and correctly think about the relationship between wealth and life. Through financial quotient education, college students can clearly understand the relative advantages of their factor endowments, play their subjective initiative to enhance their high competitiveness, and strive to cultivate their own financial quotient concept and wealth ability adapted to the society.

We should build a comprehensive and three-dimensional education and learning system covering the concept of financial intelligence in marketing specialty construction. The financial intelligence knowledge, educational means, training practice and other aspects, and organically combine with the guidance of current education theory.

\section{ACKNOWLEDGMENT}

Yajing Fang, Zhihui Wang, Xinyuan Zhang

\section{REFERENCES}

[1] Lu Yuan. On the necessity of financial quotient education in the cultivation of College Students' quality [J]. Inner Mongolia Journal of Normal University, 2014 (9). (In Chinese).

[2] Qiaochen, Zhang Yichi: General Education and Path Research of Finance and business for college students from the perspective of Internet Finance Research[J], Wuling journal, No. 4, 2018. (In Chinese).

[3] Deng Renfen: the path exploration of financial and business cultivation education for college students in the new era[J], education and occupation, Issue 19, 2015. (In Chinese).

[4] Li Zhanwen. An analysis of the necessity of strengthening financial education of college students [J]. Consumer guide,2008(9). (In Chinese).

[5] Hu Jing, ye Dan. On the financial and business education of college students [J]. Science and technology economy guide, 2018, (25). (In Chinese).

[6] Tsinghua University. A survey report on the cognition and behavior of Chinese youth in finance and business [R]. Young YanzhiKu, 2016, (1). (In Chinese). 